Article

\title{
Controlled Release of Nor- $\beta$-lapachone by PLGA Microparticles: A Strategy for Improving Cytotoxicity against Prostate Cancer Cells
}

\author{
Marcilia P. Costa ${ }^{1,2}$, Anderson C. S. Feitosa ${ }^{1}$, Fátima C. E. Oliveira ${ }^{1}$, Bruno C. Cavalcanti ${ }^{1}$, \\ Eufrânio N. da Silva Jr. ${ }^{3}$, Gleiston G. Dias ${ }^{3}$, Francisco A. M. Sales ${ }^{4}$, Bruno L. Sousa ${ }^{4}$, \\ Ito L. Barroso-Neto ${ }^{5}$, Cláudia Pessoa ${ }^{1,6}$, Ewerton W. S. Caetano ${ }^{7, *}$, Stefano Di Fiore ${ }^{8}$, \\ Rainer Fischer ${ }^{8,9}$, Luiz O. Ladeira ${ }^{10}$ and Valder N. Freire ${ }^{5}$ \\ 1 Department of Physiology and Pharmacology, Federal University of Ceará, 60430-270 Fortaleza, CE, Brazil; \\ marciliapc@ufpi.edu.br (M.P.C.); acs_feitosa@yahoo.com.br (A.C.S.F.); \\ cassiadefatima3006@gmail.com (F.C.E.O.); nunim_br@yahoo.com.br (B.C.C.); cpessoa@ufc.br (C.P.) \\ 2 Department of Pharmacy, Federal University of Piauí, 64049-550 Teresina, PI, Brazil \\ 3 Department of Chemistry, Federal University of Minas Gerais, 31270-901 Belo Horizonte, MG, Brazil; \\ eufranio@ufmg.br (E.N.S.J.); diasgg@yahoo.com.br (G.G.D.) \\ 4 Department of Physics, Federal University of Ceará, 60455-760 Fortaleza, CE, Brazil; \\ adilson.sales@gmail.com (F.A.M.S.); brunolopesdesousa@gmail.com (B.L.S.) \\ 5 Department of Analytical Chemistry and Physical Chemistry, Federal University of Ceará, \\ 60455-760 Fortaleza, CE, Brazil; itoliberato@gmail.com (I.L.B.-N.); vnffreire@gmail.com (V.N.F.) \\ 6 Oswaldo Cruz Foundation (Fiocruz), 60180-900 Fortaleza, CE, Brazil \\ 7 Department of Secondary School and Teachers College, Federal Institute of Ceará, \\ 60040-531 Fortaleza, CE, Brazil \\ 8 Fraunhofer Institute for Molecular Biology and Applied Ecology IME, 52074, Aachen, Germany; \\ stefano.difiore@ime.fraunhofer.de (S.D.F.); rainer.fischer@ime.fraunhofer.de or \\ fischer@molbiotech.rwth-aachen.de (R.F.) \\ 9 Institute for Molecular Biotechnology, RWTH Aachen University, 52074 Aachen, Germany \\ 10 Department of Physics, Federal University of Minas Gerais, 31340-550 Belo Horizonte, MG, Brazil; \\ loladeira@gmail.com \\ * Correspondence: ewcaetano@gmail.com; Tel.: +55-85-3307-3666
}

Academic Editor: Fernando Albericio

Received: 23 April 2016; Accepted: 24 June 2016; Published: 2 July 2016

\begin{abstract}
Prostate cancer is one of the most common malignant tumors in males and it has become a major worldwide public health problem. This study characterizes the encapsulation of Nor- $\beta$-lapachone (N $\beta \mathrm{L}$ ) in poly(D,L-lactide-co-glycolide) (PLGA) microcapsules and evaluates the cytotoxicity of the resulting drug-loaded system against metastatic prostate cancer cells. The microcapsules presented appropriate morphological features and the presence of drug molecules in the microcapsules was confirmed by different methods. Spherical microcapsules with a size range of $1.03 \pm 0.46 \mu \mathrm{m}$ were produced with an encapsulation efficiency of approximately $19 \%$. Classical molecular dynamics calculations provided an estimate of the typical adsorption energies of $\mathrm{N} \beta \mathrm{L}$ on PLGA. Finally, the cytotoxic activity of N $\beta$ L against PC3M human prostate cancer cells was demonstrated to be significantly enhanced when delivered by PLGA microcapsules in comparison with the free drug.
\end{abstract}

Keywords: nor- $\beta$-lapachone; lapachol; naphthoquinone; cancer; PLGA microcapsules; prostate

\section{Introduction}

Cancer is a progressive disease characterized by abnormal cell growth in which cells lose control over proliferation, overcome senescence, and become immortal and eventually malignant [1-3]. 
The molecular basis of cancer involves a combination of gain-of-function mutations in oncogenes and loss-of-function mutations in tumor-suppressor genes, often combined with epigenetic effects on gene expression [3]. Cancer is the leading cause of death worldwide [4], and death is generally caused by critical organ failure as the tumor cells spread by metastasis and seed secondary tumors [5].

Prostate cancer (PCa) is one of the most common malignant tumors in males [6], and it has become a major worldwide public health problem, reflecting high levels of morbidity and mortality [7]. The etiology of PCa, its incidence among major ethnic groups, and the molecular basis of the disease remain poorly understood. However, several factors are known to increase the risk of PCa, including senescence, family history, steroid hormone levels, pollutants, smoking, poor diet, as well as geographical and ethnic factors $[7,8]$.

PCa shows a range of clinical behaviors, from slow-growing neoplasia to aggressively metastatic tumors [9]. There is currently no cure for metastatic PCa, and most patients have a poor prognosis once the disease reaches this stage [10,11]. Although several mutations can be used as markers of disease progression and therapeutic progress [10], a better understanding of the molecular basis underlying this disease is necessary in order to develop more effective treatments, as well as to decrease side effects [11].

Numerous plant-derived drugs, such as quinones, are known to possess promising anti-cancer activity, which could be explored for developing novel therapeutic strategies against PCa [12]. Quinones are the conjugated carbonyl groups in six-membered rings. Benzoquinones, naphthoquinones and anthraquinones are structurally related to benzene, naphthalene and anthracene, respectively. Quinones have been associated with different anti-cancer, anti-bacterial, anti-fungal, and trypanocidal activities [13], and their cytotoxicity may reflect a number of underlying mechanisms including redox cycling, leading to the production of reactive oxygen species (ROS) and the alkylation of cellular nucleophiles, prompting covalent binding with proteins and/or DNA [14-16]. In animal models, quinones may cause several harmful effects, including acute cytotoxicity, immunotoxicity and carcinogenesis [14]. Nevertheless, quinones are the second main class of anti-cancer drugs for clinical use, including several compounds such as dactinomycin, daunorubicin, doxorubicin, idarubicin, mitomycin-C and mitoxantrone [15-19].

Lapachol is a naturally occurring naphthoquinone isolated from the heartwood of species belonging to the Bignoniaceae family (Tapebuia sp.) (Figure 1), which along with its derivatives have been extensively investigated for the treatment of cancer [20]. Within this group, $\beta$-lapachone, one of the most widely-studied naphthoquinones, has presented a potent cytotoxic activity against several human cancer cell lines [21,22], requiring for its bioactivation the enzyme NAD(P)H:quinone oxidoreductase 1 (NQO1). Nevertheless, in view of the high liposolubility and non-specific distribution of $\beta$-lapachone, which have restricted its clinical use, different formulations for drug delivery systems have been proposed [23], including, polymer micelles [24], gold nanoparticles and cyclodextrin complexes within liposomes $[25,26]$. Several research groups have synthesized and investigated novel lapachone analogs exhibiting higher efficacies and less toxicity than $\beta$-lapachone [16,27].

Nor- $\beta$-lapachone $(\mathrm{N} \beta \mathrm{L}), 2$,2-dimethyl-2,3-dihydronaphtho[1,2- $b$ ]furan-4,5-dione (Figure 1 ), is a lapachone derivative synthesized by the cyclization of nor-lapachol. It is considered an important anti-cancer prototype, and has been evaluated previously by our group against several cancer cell lines [22,28]. Previous reports have attested for N $\beta L$ a higher cytotoxicity towards tumor cells when compared to healthy tissues [29], while also presenting important biochemical, hematological and histological toxic effects in Wistar rats [30]. In the last few years, our group described important strategies for preparing new potent antitumor compounds. Redox center, A- and C-ring modifications of naphthoquinone prototypes, such as, for instance, $\beta$-lapachone and $N \beta L$, were the subject of a study by us $[13,31]$. We have discovered several nor- $\beta$-lapachone derivatives with highlighted antitumor activity (Scheme 1) [28,32-36]. 


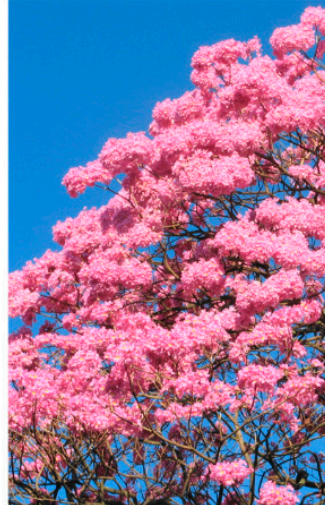

Lapacho tree (Tabebuia sp)

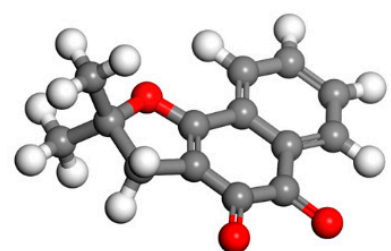

3D chemical structure of $\mathrm{N} \beta \mathrm{L}$<smiles>CC(=O)C(C)OC(C)C(=O)O</smiles>

Planar chemical structure of PLGA

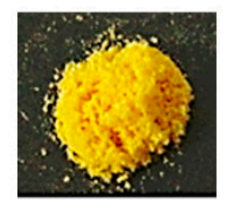

Micro N $\beta L$

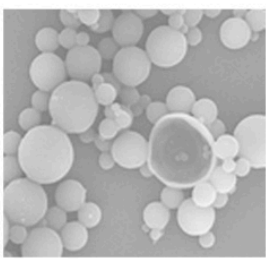

PLGA microcapsules containing $\mathrm{N} \beta \mathrm{L}$

Figure 1. Naturally occurring naphthoquinone compounds are isolated from the lapacho tree (Tabebuia sp.). Nor- $\beta$-lapachone (N $\beta \mathrm{L}$ ), a derivative prepared by the cyclization of nor-lapachol, was encapsulated in PLGA microcapsules by emulsification/solvent extraction. N $\beta$ L-loaded PLGA microcapsules appear as a lyophilized orange powder, and SEM images (magnification $\times 5000$ ) show the particle morphology.

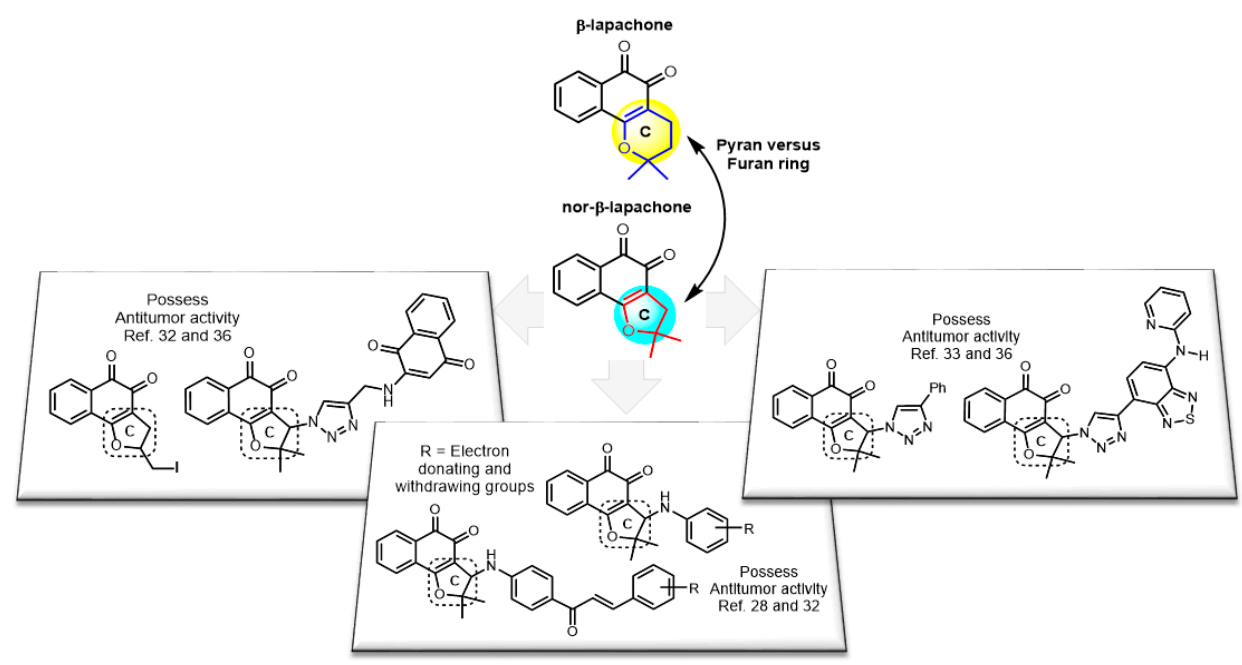

Scheme 1. Structural modifications of the prototype nor- $\beta$-lapachone.

Currently, strategies for cancer treatment based on controlled delivery systems are able to optimize the therapeutic effect of drugs and reduce toxic side effects [37-44]. In this sense, nanoparticles and microcapsules are important vehicles for drug delivery [45]. Microcapsules (1-250 $\mu \mathrm{m}$ diameter) may be prepared through a variety of techniques [46], carrying larger drug loads than nanoparticles, as well as allowing a better control over sustained release profiles [47]. Based on this fact, several anticancer agents have been encapsulated in poly(D,L-lactide-co-glycolide) (PLGA) microcapsules (Figure 1) [48-50]. PLGA is a suitable option for developing controlled-release delivery devices due to its biocompatibility, biodegradability and the gradual release of drugs over a long period of time $[39,46]$.

Here we present a PLGA-microencapsulated nor- $\beta$-lapachone formulation prepared by the emulsification/solvent evaporation method, which reduces the drug liposolubility and enables subsequent in vivo studies. Microcapsules were characterized by absorbance, Raman and infrared spectroscopy, as well as Fourier transform and differential scanning calorimetry (DSC). The, 
encapsulation efficiency, drug loading and in vitro release kinetics were determined using the spectroscopy methods listed above, whereas the interaction energy between N $\beta L$ and the PLGA's surface was estimated using classical molecular dynamics and annealing [51,52]. Scanning electron microscopy (SEM) and transmission electron microscopy (TEM) were used to evaluate the surface morphology and size distribution of the microcapsules, while the surface charge was determined by measuring the zeta potential. The in vitro cytotoxicity of the N $\beta L$-loaded microcapsules was investigated through cellular viability assays against several human prostate cancer cell lines, using empty PLGA microcapsules and a free N $\beta \mathrm{L}$ drug as controls. As discussed above, the antitumor activity of $\beta$-lapachone (quinone from lapachol group) was improved by the preparation of microparticles for use in controlled release. To the best of our knowledge, this is the first study involving controlled release of nor- $\beta$-lapachone microparticles and it represents a new strategy to improve the antitumor activity of this important naphthoquinone.

\section{Results and Discussion}

PLGA microcapsule formulations were prepared by the emulsion solvent evaporation method, and the simple emulsion method was the most satisfactory for the preparation of N $\beta$ L-loaded microcapsules. Briefly, N $\beta$ L was dissolved in a polymeric solution of PLGA in dichloromethane and emulsified with aqueous PVA solution ( $2 \mathrm{~min} / 11,000 \mathrm{rpm}$ ). In the process, stirring was performed for another four hours after the emulsification to evaporate the dichloromethane and produce a suspension of microparticles which were recovered by centrifugation and washed twice with deionized water. The best formulation was generated using PLGA 50:50 (100 mg), N $\beta L(5 \mathrm{mg}), 2 \%$ PVA solution $(25 \mathrm{~mL})$ and dichloromethane $(10 \mathrm{~mL})$. SEM and TEM analysis confirmed that the formulated microcapsules had appropriate morphological characteristics, such as a regular spherical shape and a smooth nonporous surface. The absence of drug crystals or clusters and the characteristic hollow structure of microcapsules were also confirmed. A sample of $100 \mathrm{~N} \beta \mathrm{L}$-loaded PLGA microcapsules exhibited a bimodal size distribution with average diameters of $1.03 \pm 0.46 \mu \mathrm{m}$ S.D. (standard deviation, Figure 2a). The most frequent diameter was $0.68 \mu \mathrm{m}(8.4 \%)$, followed by $1.10 \mu \mathrm{m}(7.2 \%)$. The largest observed diameter was $2.46 \mu \mathrm{m}(0.39 \%)$ and the smallest was $0.14 \mu \mathrm{m}(0.39 \%)$, with a mass median diameter close to $6 \mu \mathrm{m}$ as estimated by using the Hatch-Choate equation. The calculated zeta potential of $-23.4 \pm 0.35 \mathrm{mV}$ reflects the presence of $\mathrm{N} \beta \mathrm{L}$ on the particle surface, which was also confirmed by infrared (Figure $2 b$ ) and Raman spectroscopy (Figure 2c). The last-revealed four peaks at 1572, 1594, 1614 and $1648 \mathrm{~cm}^{-1}$ in the spectrum represented the N $\beta$-loaded microcapsules which were absent in the spectrum for the empty particles (not shown in Figure 2). These Raman bands were related to the peaks at 1571, 1591, 1614 and $1647 \mathrm{~cm}^{-1}$ observed in the pure N $\beta \mathrm{L}$ spectrum. The first two modes $\left(1571,1591 \mathrm{~cm}^{-1}\right)$ can be assigned to benzene ring breathing modes where two $C=C$ bonds on opposite sides of the hexagonal benzene ring perform symmetric stretching motions. The 1614 and $1647 \mathrm{~cm}^{-1}$ normal modes can be assigned to $\mathrm{C}=\mathrm{O}$ bonds stretching in the naphthoquinone region of $\mathrm{N} \beta \mathrm{L}$. The FT-IR spectrum of the PLGA microcapsules loaded with N $\beta$ L follows closely the spectrum of the unloaded microparticles, exhibiting a series of absorption bands between 490 and $3380 \mathrm{~cm}^{-1}$. In the region between 1500 and $1670 \mathrm{~cm}^{-1}$ one can see a set of characteristic peaks of N $\beta \mathrm{L}$ which are also present in the N $\beta L$-loaded PLGA microcapsules, but which do not appear in the empty formulation (Figure 2b). 

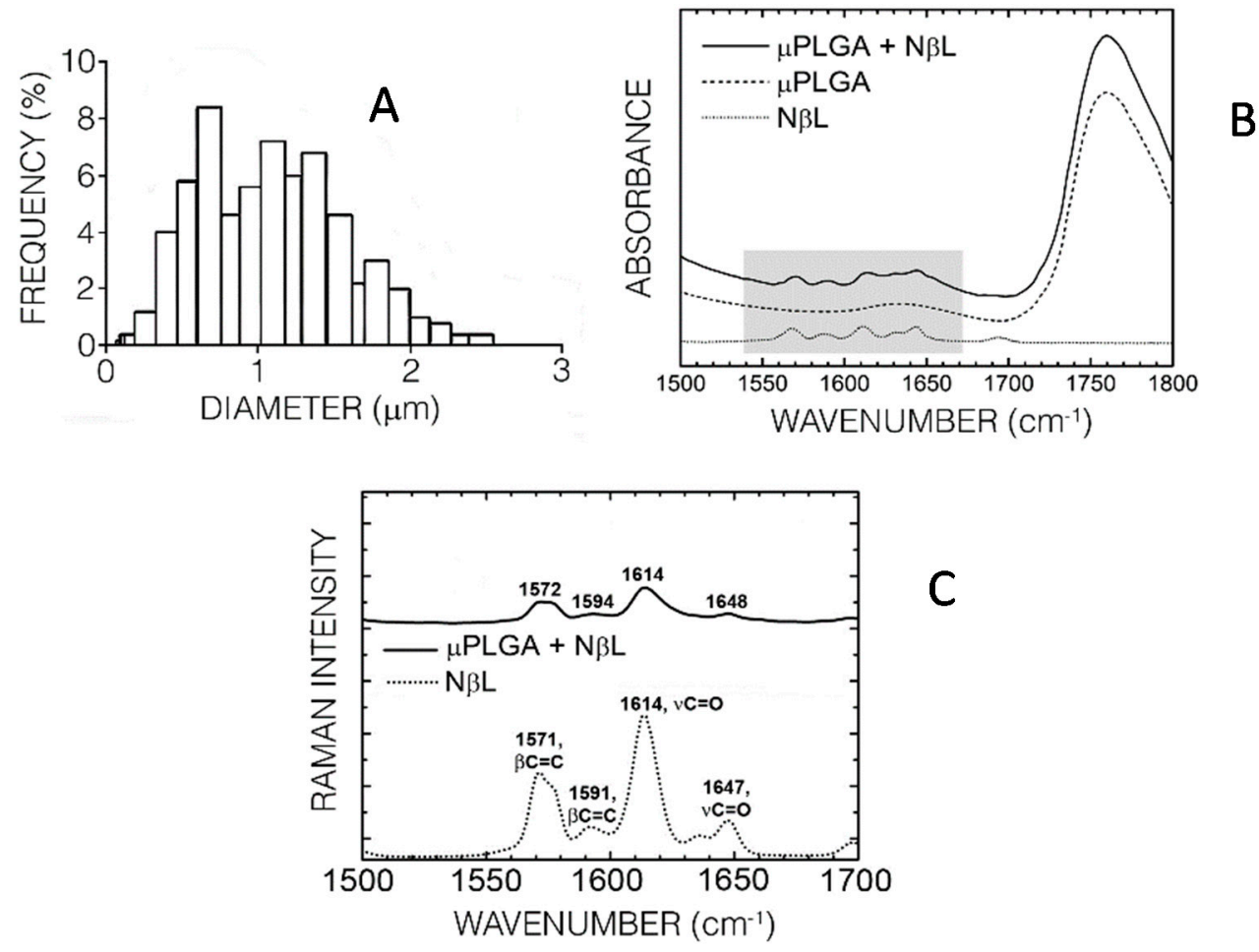

Figure 2. Characterization of the N $\beta$ L-loaded PLGA microcapsules. (A) Size distribution of 500 microcapsules; (B,C) Respectively, infrared and Raman spectra of pure N $\beta$ L (dotted line), empty PLGA microcapsules (dashed line) and N $\beta$ L-loaded PLGA microcapsules (black line). The shading in the IR absorption spectrum highlights the wavenumber region depicted in the Raman plot. Raman band wavenumbers and their corresponding normal mode assignments are depicted as well.

A PLGA chain containing 100 monomers of lactic acid and 100 monomers of glycolic acid in a random sequence was optimized using classical annealing, producing a highly irregular polymer consisting of two asymmetric clusters connected by a small polymer bridge. A few indentations, cavities and clefts can be seen between these clusters where a single $\mathrm{N} \beta \mathrm{L}$ molecule can be docked. Using Monte Carlo calculations, the surface of the annealed polymer was probed and 50 adsorption sites were found with adsorption energies ranging from $-9.85 \mathrm{kcal} \cdot \mathrm{mol}^{-1}$ (indicating physisorption or weak attractive interaction) to $-31.5 \mathrm{kcal} \cdot \mathrm{mol}^{-1}$ (indicating chemisorption or strong attractive interaction). This energy range of adsorption geometries provides some insight into the drug loading and entrapment efficiency as well as the initial phase of drug release (burst release, see below) by the microcapsules. Classical and quantum molecular dynamics simulations, on the other hand, can in principle be used to predict the effect of water solvation and $\mathrm{pH}$ on the process of drug release from the surface of PLGA microcapsules and nanoparticles. In Figure 3, three adsorption configurations are presented in increasing order of binding energy. Figure 3a depicts the structure with the smallest binding energy $\left(-9.85 \mathrm{kcal} \cdot \mathrm{mol}^{-1}\right)$. Figure $3 \mathrm{~b}$ reveals a configuration with intermediate adsorption energy $\left(-18.1 \mathrm{kcal} \cdot \mathrm{mol}^{-1}\right)$, while Figure $3 \mathrm{c}$ is the adsorption geometry with the largest binding energy $\left(-31.5 \mathrm{kcal} \cdot \mathrm{mol}^{-1}\right)$. In the last case, the N $\beta \mathrm{L}$ molecule appears inserted in a cleft on the larger cluster surface, with just one side not involved in interactions with the PLGA chain. We note that a recent work [53] on the release of drugs from mesoporous matrices revealed that this process becomes slower as the pore size is reduced. Computer simulations were carried out in order to understand this phenomenon, showing that the attraction of drug molecules to the walls of pores is stronger for smaller pores. The authors concluded that the drug release kinetics from mesoporous matrices must take into account the strength of the drug attraction by the mesoporous matrix. This motivates us to believe that there is a connection between drug-substrate binding energy values and the rate of drug release. 
A

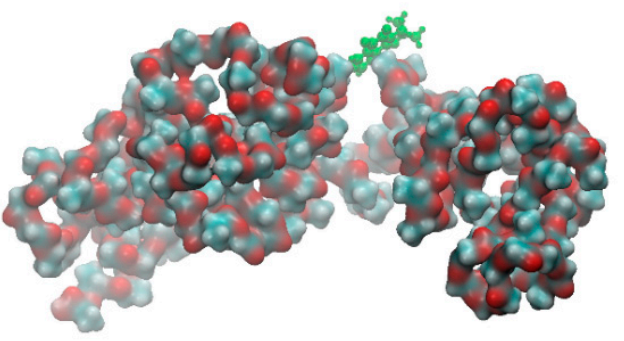

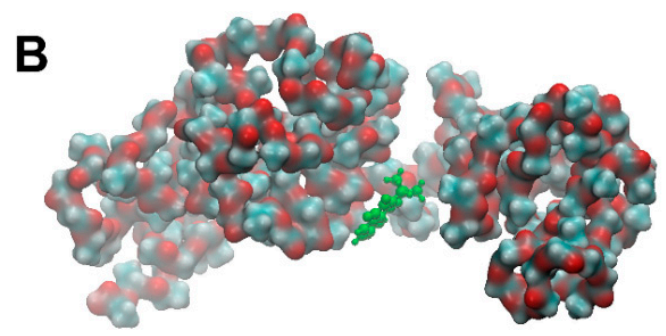

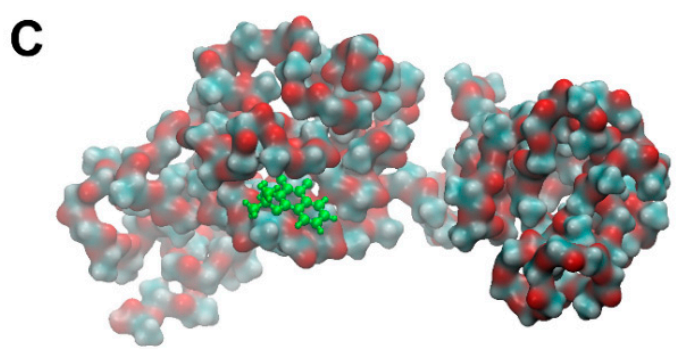

Figure 3. Classical molecular dynamics simulation of a single N $\beta$ L molecule adsorbed on a PLGA microcapsule surface. (A) Structure with smallest binding energy; (B) Configuration with intermediate adsorption energy; (C) Adsorption geometry with largest binding energy.

The DSC trace of the pure N $\beta$ L showed a sharp endothermic peak at $192.04{ }^{\circ} \mathrm{C}$, which corresponds to its melting point. The thermal gravimetric analysis (TGA) of the PLGA microcapsules containing $\mathrm{N} \beta \mathrm{L}$ showed a mass gain due to decomposition. At the same time, thermal analysis has established that the incorporation N $\beta \mathrm{L}$ changes the thermal properties of the microcapsules. The absence of the peak corresponding to the melting point of the pure N $\beta L$ in the PLGA microcapsules containing $\mathrm{N} \beta \mathrm{L}$ suggests that the drug was dissolved or molecularly dispersed within the polymer in an amorphous fashion. The formulation with a 1:20 drug/polymer ratio showed the maximum drug encapsulation efficiency, with a total drug loading of $1.19 \% \pm 0.07 \%$, and an encapsulation efficiency of $19.36 \% \pm 1.15 \%$. In vitro release experiments were performed by the dialysis method. Briefly, approximately $150 \mathrm{mg}$ of N $\beta$ L-loaded PLGA microparticles were put into a dialysis bag and suspended in $200 \mathrm{~mL}$ of release medium (PBS, pH 7.4). The suspensions were incubated in glass tubes in an incubation shaker under stirring at $100 \mathrm{rpm}$ at $37^{\circ} \mathrm{C}$. Samples of the solutions were removed at predetermined time intervals and the concentration of $\mathrm{N} \beta \mathrm{L}$ was analyzed using a spectrophotometer at $450 \mathrm{~nm}$. Release profiles were calculated in terms of the cumulative releasing percentage of $\mathrm{N} \beta \mathrm{L}$ $(\%)$ over the incubation time. The release profile of N $\beta L$ from the PLGA microcapsules in this study occurred in two stages (initial burst release phase followed by a second gradual release phase). Thus, drug release from the microcapsules followed a biphasic profile, with an initial burst effect within $24 \mathrm{~h}(\sim 90 \%)$ followed by sustained release for an extended time period (Figure $4 \mathrm{a})$. This burst release effect can be assigned to the release of adsorbed drug molecules, which results in greater initial drug diffusivity [54].

A MTT assay was used to evaluate the cytotoxic effect of the free and encapsulated forms of N $\beta \mathrm{L}$ against three prostate cancer cell lines. The $\mathrm{IC}_{50}$ data for PC3M cells are presented in Figure $4 \mathrm{~b}$. As discussed by Pérez-Sacau et al. [55], the compounds can be classified as highly active ( $\mathrm{IC}_{50}<1 \mu \mathrm{g} \cdot \mathrm{L}^{-1}$ ), moderately active $\left(1 \mu \mathrm{g} \cdot \mathrm{mL}^{-1}<\mathrm{IC}_{50}<10 \mu \mathrm{g} \cdot \mathrm{mL}^{-1}\right)$, or inactive $\left(10 \mu \mathrm{g} \cdot \mathrm{mL}^{-1}>\mathrm{IC}_{50}\right)$. Therefore, the N $\beta L$-loaded PLGA microcapsules have demonstrated effective cytotoxic activity against all the cell lines with the inhibitory activity of N $\beta$ L-loaded PLGA microcapsules against PC3M cells exceeding the cytotoxicity of free $\mathrm{N} \beta \mathrm{L}$ (Figure $3 \mathrm{~b}$ ). After incubation for $24 \mathrm{~h}$, the $\mathrm{IC}_{50}$ values of the free and encapsulated $\mathrm{N} \beta \mathrm{L}$ formulations were $1.887(1.54-2.31)$ and $2.442(1.86-3.21) \mu \mathrm{g} \cdot \mathrm{mL}^{-1}$, respectively. After $72 \mathrm{~h}$, the corresponding values were $2.045(1.971-2.122)$ and $1.046(0.82-1.34) \mu \mathrm{g} \cdot \mathrm{mL}^{-1}$, and after $96 \mathrm{~h}$ they were $1.787(1.63-1.96)$ and $1.401(1.20-1.64)$. The drug was mostly toxic towards PC3M 
cells within the first $24 \mathrm{~h}$ and no additional cytotoxicity was observed until $96 \mathrm{~h}$, probably due to the reduction of the drug concentration in the medium. After incubation for $72 \mathrm{~h}$, the $\mathrm{IC}_{50}$ values of the free and encapsulated $\mathrm{N} \beta \mathrm{L}$ formulations were significantly different according to ANOVA Tukey's test. We suggest that in $72 \mathrm{~h}$, the activity of the N $\beta$ L-loaded PLGA microcapsules was increased because of the higher concentration of the drug within the cells. It was not observed any inhibitory effect of empty PLGA microcapsules over the proliferation of any cell line even at the maximum concentration of $10 \mu \mathrm{M}\left(2.28 \mu \mathrm{g} \cdot \mathrm{mL}^{-1}\right)$. Microscopy revealed that the microcapsules adhered to the cell surface and were taken up by phagocytosis after a few minutes (Figure 4c). Pure N $\beta L$ and PLGA microcapsules containing $\mathrm{N} \beta \mathrm{L}$ did not present proliferative inhibition at the maximum concentration of $2.28 \mu \mathrm{g} \cdot \mathrm{mL}^{-1}(10 \mu \mathrm{M})$ on PBMC.
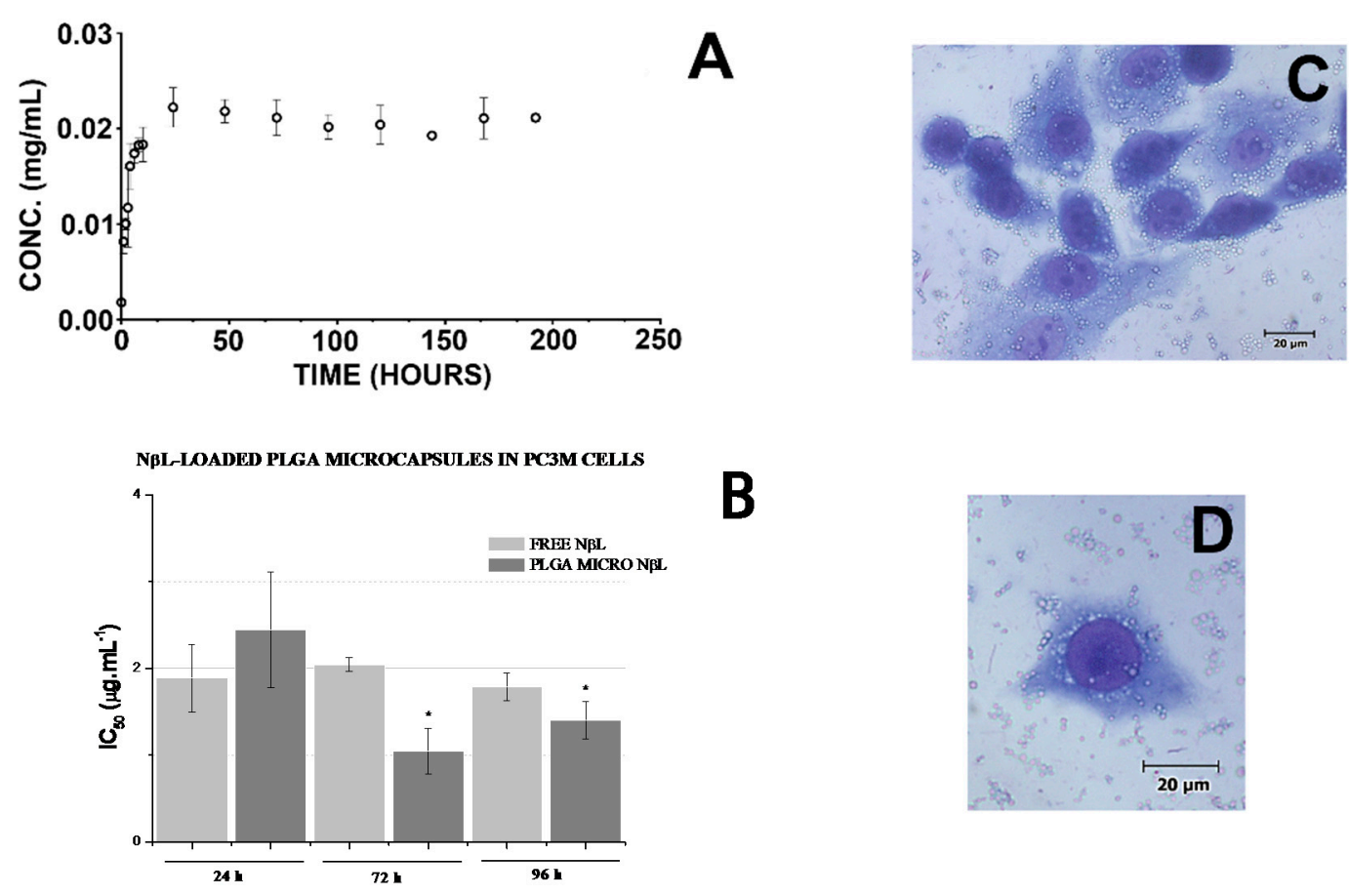

Figure 4. Drug release and in vitro assays. (A) Release profile of $N \beta L$ from PLGA microcapsules under physiological conditions at $37^{\circ} \mathrm{C}$ in PBS buffer (pH 7.4) $(n=3)$. Data are presented as mean values \pm S.E.M. (standard error of the mean); (B) $\mathrm{IC}_{50}$ values for free and encapsulated $\mathrm{N} \beta \mathrm{L}$ after 24, 72 and $96 \mathrm{~h}$ incubation with PC3M human prostate cancer cells. Data are presented as mean values \pm S.E.M. from two independent experiments performed in duplicate $(n=4)$. ${ }^{*}$ Significant difference from the PLGA micro N $\beta$ L $(24 \mathrm{~h})$ group $(p<0.05)$ according to ANOVA Tukey's test; (C,D) Microscopic analysis of hematoxylin/eosin-stained PC3M cells after $1 \mathrm{~h}$ of treatment with PLGA microcapsules containing N $\beta$ L. The cells were analyzed by light microscopy $(400 \times)$.

\section{Materials and Methods}

Lapachol (2-hydroxy-3-(3'-methyl-2'-butenyl)-1,4-naphthoquinone) was extracted from the heartwood of Tabebuia sp. (Tecoma). Initially, a saturated aqueous sodium carbonate solution was added to the sawdust of ipe After the formation of the lapachol sodium salt, hydrochloric acid was added, allowing the precipitation of lapachol. After filtration, a yellow solid was obtained. This solid was purified by a series of recrystallizations with appropriate solvents. Nor-lapachol was prepared from lapachol by Hooker oxidation reaction [56]. Nor- $\beta$-lapachone was prepared by acid catalyzed cyclization from nor-lapachol as previously described [57]. The preparation and characterization of N $\beta$ L-loaded PLGA microcapsules was discussed above for better understanding of the reader. PLGA microparticles nor- $\beta$-lapachone formulation was prepared by the emulsification in Ultra-Tturrax T25, IKA, Germany. The scanning electron microscope JEOL JSM 6360 LV (JEOL 
Europe SA, Croissy-sur-Seine, France) was used to carry out the measurements. The zeta potential of the PLGA microparticles was determined using Zetasizer Nano ZS (Malvern Instruments Ltd, Worcestershire, UK). Experimental measurements of the UV absorption spectra were carried out using the Varian Cary 5000 UV-visible NIR spectrophotometer (Varian Inc., Cary, NC, USA); all measurements were done on pellets made from $\mathrm{KBr}$ mixed with the sample powder. FT-IR spectra were all performed in a FTLA 2000 series laboratory instrument (ABB Bomem Inc., Québec City, QC, Canada); all spectra were run on a $\mathrm{KBr}$ pellet (100 mg, $1 \mathrm{wt} \%$ ) and collected over 40 scans at a resolution of $2 \mathrm{~cm}^{-1}$. The differential scanning calorimetry (DSC) were analyzed using a DSC-60 (Shimadzu Corporation, Kyoto, Japan) thermal analyzer; the samples were heated from 25 to $220^{\circ} \mathrm{C}$ at a heating rate of $10^{\circ} \mathrm{C} / \mathrm{min}$ under azote atmosphere $(50 \mathrm{~mm} / \mathrm{min})$. Thermogravimetric analysis (TGA) was performed using a DTG-60H (Shimadzu Corporation, Kyoto, Japan); the samples were heated from 25 to $700{ }^{\circ} \mathrm{C}$ at $10{ }^{\circ} \mathrm{C} / \mathrm{min}$ (azote atmosphere) and compared. The drug content and loading efficiency were determined in triplicate using a Varian Cary 5000 UV-visible NIR (Varian Inc., Cary, NC, USA) spectrophotometer. To extract the N $\beta \mathrm{L}$, known weights $(\sim 2 \mathrm{mg})$ of the lyophilized microparticles were broken with a mixture of dichloromethane and methanol (3:2) under ultrasound agitation for $30 \mathrm{~min}$ to ensure the complete polymer dissolution and release of the drug. The solubilized drug was quantified at $450 \mathrm{~nm}$. In in vitro release tests were used an incubation shaker Cientec, CT712RTN (Cientec, SP, Brazil) and a DTX880 Multimode Detector (Beckman Coulter Inc., Pesadena, CA, USA) spectrophotometer. The human cell lines used in this work were HL-60 (leukemia), OVCAR-8 (ovarian), HCT-116 (colon), DU145 (prostate), PC3M (prostate) and PC3 (prostate), all obtained from the National Cancer Institute (Bethesda, MD, USA). The cells were maintained in RPMI 1640 medium supplemented with $10 \%$ fetal bovine serum, $100 \mathrm{U} \mathrm{mL}^{-1}$ penicillin, and $100 \mu \mathrm{g} \mathrm{mL}^{-1}$ streptomycin at $37^{\circ} \mathrm{C}$ with $5 \% \mathrm{CO}_{2}$ atmosphere. The cell viability was determined by the reduction of a yellow dye 3-(4,5-dimethyl-2-thiazolyl)2,5-diphenyl-2H-tetrazolium bromide (MTT) to a blue formazan product. Briefly, the cells were distributed in 96-well plates (OVCAR-8, DU145, PC3M and PC3 for $0.1 \times 10^{6}$ cells/well in $100 \mu \mathrm{L}$ of medium, $0.7 \times 10^{5}$ cells/well for HCT-116 in $100 \mu \mathrm{L}$ of medium and HL-60 for $0.3 \times 10^{6}$ cells/well in $100 \mu \mathrm{L}$ of medium). After $24 \mathrm{~h}, \mathrm{~N} \beta \mathrm{L}$ dissolved in DMSO, empty PLGA microparticles and N $\beta$ L-loaded PLGA microparticles suspended in PBS pH 7.4 at concentrations in the $1-10 \mu \mathrm{M}$ range were added to each well. Doxorubicin was used as positive control $(0.02-8.6 \mu \mathrm{M})$. Control groups received the same amount of DMSO. After $72 \mathrm{~h}$ of incubation, the plates were centrifuged and the medium was replaced with a fresh medium $(150 \mu \mathrm{L})$ containing MTT (0.5 mg. $\left.\mathrm{mL}^{-1}\right)$. Only the prostate cancer cell lines (DU145, PC3M and PC3) were evaluated three times (within 24, 72 and $96 \mathrm{~h}$ ). Three hours later, the plates were centrifuged, and the MTT formazan product was dissolved in $150 \mu \mathrm{L}$ DMSO. The absorbance was measured using a multiplate reader (DTX880 Multimode Detector, Beckman Coulter Inc., Pesadena, CA, USA). Adherence of PLGA microcapsules was observed using an optic microscope (Olympus, Tokyo, Japan).

\section{Conclusions}

The present study was designed to develop and characterize N $\beta$ L-loaded PLGA microcapsules and to determine their cytotoxic activity against three human prostate cancer cell lines. Microcapsules obtained by emulsion solvent evaporation showed appropriate morphological features and a biphasic drug release profile. Drug loading was confirmed by spectroscopy, and classical molecular dynamics simulations indicated that N $\beta L$ can be adsorbed on the surface of PLGA microcapsules with binding energies as large as $-32 \mathrm{kcal} \mathrm{mol}^{-1}$ (chemisorption), contributing to the initial phase of the drug release process. Despite the relatively low encapsulation efficiency, the N $\beta$ L-loaded PLGA microcapsules showed cytotoxic activity against all three cell lines, and were more cytotoxic than the free drug when tested against PC3M cells. Based on these data, we propose PLGA microcapsules containing N $\beta L$ as a promising drug delivery system, suitable for in vivo model analysis of prostate cancer.

Acknowledgments: The authors would like to thank the Brazilian Research Agency CNPq for financial support through the project 550579/2012-5 (Edital Jovens Pesquisadores) and PVE 401193/2014-4. E. W. S. C. received 
financial support from CNPq project 307843/2013-0, FAPEMIG, CAPES/PROCAD and FUNCAP (Fundação Cearense de Apoio ao Desenvolvimento Científico e Tecnológico, Brazil). C. P. received financial support from CNPq through the projects 555020/2010-0 and 490045/2011-1 (FUNCAP-PRONEX). We also thank A. C. S. Feitosa, F. C. E. Oliveira, and G. C. Dias for their help in designing and carrying out some of the experimental measurements.

Author Contributions: E.N da Silva Júnior, C. Pessoa, E. W. S. Caetano, L. O. Ladeira and V. N. Freire conceived and designed the experiments; M. P. Costa, A. C. S. Feitosa, F. C. O. E. Oliveira, B. C. Cavalcanti, G. G. Dias, F. A. M. Sales, B. L. Sousa, S. Di Fiore, R. Fischer and I. L. Barroso-Neto performed the experiments; E.N da Silva Júnior, C. Pessoa, E. W. S. Caetano, M. P. Costa and V. N. Freire analyzed the data; E.N da Silva Júnior, C. Pessoa, E. W. S. Caetano, L. O. Ladeira, V. N. Freire and R. Fischer contributed reagents/materials/analysis tools; E.N da Silva Júnior, M. P. Costa, E. W. S. Caetano and V. N. Freire wrote the paper.

Conflicts of Interest: The authors declare no conflict of interest

\section{Abbreviations}

The following abbreviations are used in this manuscript:

$\begin{array}{ll}\text { N } \beta L & \text { Nor- } \beta \text {-lapachone } \\ \text { PLGA } & \text { Poly(D,L-lactide-co-glycolide) } \\ \text { PCa } & \text { Prostate cancer } \\ \text { ROS } & \text { Reactive oxygen species } \\ \text { DNA } & \text { Deoxyribonucleic acid } \\ \text { NQO1 } & \text { NAD(P)H:quinone oxidoreductase 1 } \\ \text { DSC } & \text { Differential scanning calorimetry } \\ \text { SEM } & \text { Scanning electron microscopy } \\ \text { TEM } & \text { Transmission electron microscopy }\end{array}$

\section{References}

1. Lobo, N.A.; Shimono, Y.; Qian, D.; Clarke, M.F. The Biology of Cancer Stem Cells. Annu. Rev. Cell Dev. Biol. 2007, 23, 675-699. [CrossRef] [PubMed]

2. Bertram, J.S. The molecular biology of cancer. Mol. Asp. Med. 2001, 21, 167-223. [CrossRef]

3. De Berardinis, R.J.; Lum, J.J.; Hatzivassiliou, G.; Thompson, C.B. The Biology of Cancer: Metabolic Reprogramming Fuels Cell Growth and Proliferation. Cell Metab. 2008, 7, 11-20. [CrossRef] [PubMed]

4. Visvader, J.E. Cells of origin in cancer. Nature 2011, 469, 314-322. [CrossRef] [PubMed]

5. Yachida, S.; Jones, S.; Bozic, I.; Antal, T.; Leary, R.; Fu, B.; Kamiyama, M.; Hruban, R.H.; Eshleman, J.R.; Nowak, M.A.; et al. Distant metastasis occurs late during the genetic evolution of pancreatic cancer. Nature 2010, 467, 1111-1118. [CrossRef] [PubMed]

6. Abate-Shen, C.; Shen, M.M. Diagnostics: The prostate-cancer metabolome. Nature 2009, 457, 799-800. [CrossRef] [PubMed]

7. Gong, M.; Dong, W.; Shi, Z.; Xu, Y.; Ni, W.; An, R. Genetic Polymorphisms of GSTM1, GSTT1, and GSTP1 with Prostate Cancer Risk: A Meta-Analysis of 57 Studies. PLoS ONE 2012, 7, 1-12. [CrossRef] [PubMed]

8. Kpoghomou, M.A.; Soatiana, J.E.; Kalembo, F.W.; Bishwajit, G.; Sheng, W. UGT2B17 Polymorphism and Risk of Prostate Cancer: A Meta-Analysis. ISRN Oncol. 2013, 3, 1-7. [CrossRef] [PubMed]

9. Beltran, H.; Yelensky, R.; Frampton, G.M.; Park, K.; Downing, S.R.; MacDonald, T.Y.; Jarosz, M.; Lipson, D.; Tagawa, S.T.; et al. Targeted Next-generation Sequencing of Advanced Prostate Cancer Identifies Potential Therapeutic Targets and Disease Heterogeneity. Eur. Urol. 2013, 63, 920-926. [CrossRef] [PubMed]

10. Choucair, K.; Ejdelman, J.; Brimo, F.; Aprikian, A.; Chevalier, S.; Lapointe, J. PTEN genomic deletion predicts prostate cancer recurrence and is associated with low AR expression and transcriptional activity. BMC Cancer 2012, 12, 1-9. [CrossRef] [PubMed]

11. Vis, A.N.; Fritz, H.; Schröder, F.H. Key targets of hormonal treatment of prostate cancer. Part 1: the androgen receptor and steroidogenic pathways. BJU Int. 2009, 104, 438-448. [CrossRef] [PubMed]

12. Li, C.J.; Wang, C.; Pardee, A.B. Induction of Apoptosis by $\beta$-Lapachone in Human Prostate Cancer Cells. Cancer Res. 1995, 55, 3712-3715. [PubMed]

13. De Castro, S.L.; Emery, F.S.; da Silva Júnior, E.N. Synthesis of quinoidal molecules: strategies towards bioactive compounds with an emphasis on lapachones. Eur. J. Med. Chem. 2013, 69, 678-700. [CrossRef] [PubMed] 
14. Bolton, J.L.; Trush, M.A.; Penning, T.M.; Dryhurst, G.; Monks, T.J. Role of Quinones in Toxicology. Chem. Res. Toxicol. 2000, 13, 135-160. [CrossRef] [PubMed]

15. Sagar, S.; Kaur, M.; Minneman, K.P.; Bajic, V.B. Anti-cancer activities of diospyrin, its derivatives and analogues. Eur. J. Med. Chem. 2010, 45, 519-530. [CrossRef] [PubMed]

16. Vessecchi, R.; Emery, F.S.; Galembeck, S.E.; Lopes, N.P. Fragmentation studies and electrospray ionization mass spectrometry of lapachol: Protonated, deprotonated and cationized species. Rapid Commun. Mass Spectrom. 2010, 24, 2101-2108. [CrossRef] [PubMed]

17. Marinho-Filho, J.D.B.; Bezerra, D.P.; Araújo, A.J.; Montenegro, R.C.; Pessoa, C.; Diniz, J.C.; Viana, F.A.; Pessoa, O.D.L.; Silveira, E.R.; Moraes, M.O.; et al. Oxidative stress induction by (+)-cordiaquinone J triggers both mitochondria-dependent apoptosis and necrosis in leukemia cells. Chem. Biol. Interact. 2010, 183, 369-379. [CrossRef] [PubMed]

18. Salustiano, E.J.S.; Netto, C.D.; Fernandes, R.F.; Silva, A.J.M.; Bacelar, T.S.; Castro, C.P.; Buarque, C.D.; Maia, R.C.; Rumjanek, V.M.; Costa, P.R.R. Comparison of the cytotoxic effect of lapachol, $\alpha$-lapachone and pentacyclic 1,4-naphthoquinones on human leukemic cells. Investig. New Drugs 2010, 28, 139-144. [CrossRef] [PubMed]

19. Siegel, D.; Yan, C.; Ross, D. NAD(P)H:quinone oxidoreductase 1 (NQO1) in the sensitivity and resistance to antitumor quinones. Biochem. Pharm. 2012, 83, 1033-1040. [CrossRef] [PubMed]

20. Ríos-Luci, C.; Bonifazi, E.L.; León, L.G.; Montero, J.C.; Burton, G.; Pandiella, A.; Misico, R.I.; Padrón, J.M. $\beta$-Lapachone analogs with enhanced antiproliferative activity. Eur. J. Med. Chem. 2012, 53, $264-274$. [CrossRef] [PubMed]

21. Li, C.J.; Li, Y.Z.; Pinto, A.V.; Pardee, A.B. Potent inhibition of tumor survival in vivo by $\beta$-lapachone plus taxol: Combining drugs imposes different artificial checkpoints. PNAS 1999, 96, 13369-13374. [CrossRef] [PubMed]

22. Da Silva Júnior, E.N.; Souza, M.C.B.V.; Pinto, A.V.; Pinto, M.C.F.R.; Goulart, M.O.F.; Barros, F.W.A.; Pessoa, C.; Costa-Lotufo, L.V.; Montenegro, R.C.; Moraes, M.O.; Ferreira, V.F. Synthesis and potent antitumor activity of new arylamino derivatives of nor- $\beta$-lapachone and nor- $\alpha$-lapachone. Bioorg. Med. Chem. 2007, 15, 7035-7041. [CrossRef] [PubMed]

23. Seoane, S.; Díaz-Rodríguez, P.; Sendon-Lago, J.; Gallego, R.; Pérez-Fernández, R.; Landin, M. Administration of the optimized $\beta$-Lapachone-poloxamer-cyclodextrin ternary system induces apoptosis, DNA damage and reduces tumor growth in a human breast adenocarcinoma xenograft mouse model. Eur. J. Pharm. Biopharm. 2013, 84, 497-504. [CrossRef] [PubMed]

24. Blanco, E.; Bey, E.A.; Dong, Y.; Weinberg, B.D.; Sutton, D.M.; Boothman, D.A.; Gao, J. $\beta$-Lapachone-containing PEG-PLA polymer micelles as novel nanotherapeutics against NQO1-overexpressing tumor cells. J. Control. Release 2007, 122, 365-374. [CrossRef] [PubMed]

25. Jeong, S.Y.; Park, S.J.; Yoon, S.M.; Jung, J.; Woo, H.N.; Yi, S.L.; Song, S.Y.; Park, H.J.; Kim, C.; Lee, J.S.; et al. Systemic delivery and preclinical evaluation of Au nanoparticle containing $\beta$-lapachone for radiosensitization. J. Control. Release 2009, 139, 239-245. [CrossRef] [PubMed]

26. Cavalcanti, I.M.F.; Mendonça, E.A.M.; Lira, M.C.B.; Honrato, S.B.; Camara, C.A.; Amorim, R.V.S.; Mendes-Filho, J.; Rabello, M.M.; Hernandes, M.Z.; Ayala, A.P.; et al. The encapsulation of $\beta$-lapachone in 2-hydroxypropyl-b-cyclodextrin inclusion complex into liposomes: A physicochemical evaluation and molecular modeling approach. Eur. J. Pharm. Sci. 2011, 44, 332-340. [CrossRef] [PubMed]

27. Wei, P.; Zhang, X.; Tu, S.; Yan, S.; Ying, H.; Ouyang, P. New potential inhibitors of DNA topoisomerase. Part II: Design and synthesis of $\alpha$-lapachone derivatives under microwave irradiation. Bioorg. Med. Chem. Lett. 2009, 19, 828-830. [CrossRef] [PubMed]

28. Da Silva Júnior, E.N.; Deus, C.F.; Cavalcanti, B.C.; Pessoa, C.; Costa-Lotufo, L.V.; Montenegro, R.C.; Moraes, M.O.; Pinto, M.C.F.R.; Simone, C.A.; Ferreira, V.F.; et al. 3-Arylamino and 3-Alkoxy-nor- $\beta$-lapachone Derivatives: Synthesis and Cytotoxicity against Cancer Cell Lines. J. Med. Chem. 2010, 53, 504-508. [CrossRef] [PubMed]

29. Cavalcanti, B.C.; Barros, F.W.A.; Cabral, I.O.; Ferreira, J.R.O.; Magalhães, H.I.F.; Júnior, H.V.N.; da Silva Júnior, E.M.; Abreu, F.C.; Costa, C.O.; Goulart, M.O.F.; et al. Preclinical Genotoxicology of Nor- $\beta$-lapachone in Human Cultured Lymphocytes and Chinese Hamster Lung Fibroblasts. Chem. Res. Toxicol. 2011, 24, 1560-1574. [CrossRef] [PubMed] 
30. Almeida, E.R.; Lucena, F.R.S.; Silva, C.V.N.S.; Costa-Junior, W.S.; Cavalcanti, J.B.; Couto, G.B.L.; Silva, L.L.S.; Mota, D.L.; Silveira, A.B.; Sousa Filho, S.D.; et al. Toxicological Assessment of $\beta$-lapachone on Organs from Pregnant and Non-pregnant Rats. Phytother. Res. 2009, 23, 1276-1280. [CrossRef] [PubMed]

31. Jardim, G.A.M.; da Silva Júnior, E.N.; Bower, J.F. Overcoming naphthoquinone deactivation: rhodium-catalyzed C-5 selective $\mathrm{C}-\mathrm{H}$ iodination as a gateway to functionalized derivatives. Chem. Sci. 2016, 7, 3780-3784. [CrossRef]

32. Jardim, G.A.M.; Guimarães, T.T.; Pinto, M.C.F.R.; Cavalcanti, B.C.; de Farias, K.M.; Pessoa, C.; Gatto, C.C.; Nair, D.K.; Namboothiri, I.N.N.; da Silva Júnior, E.N. Naphthoquinone-based chalcone hybrids and derivatives: Synthesis and potent activity against cancer cell lines. Med. Chem. Commun. 2015, 6, 120-130. [CrossRef]

33. Da Cruz, E.H.G.; Carvalho, P.H.P.R.; Corrêa, J.R.; Silva, D.A.C.; Diogo, E.B.T.; de Souza Filho, J.D.; Cavalcanti, B.C.; Pessoa, C.; de Oliveira, H.C.B.; Guido, B.C.; et al. Design, synthesis and application of fluorescente 2,1,3-benzothiadiazole-triazole-linked biologically active lapachone derivatives. New J. Chem. 2014, 38, 2569-2580. [CrossRef]

34. Cavalcanti, B.C.; Cabral, I.O.; Rodrigues, F.A.R.; Barros, F.W.A.; Rocha, D.D.; Magalhães, H.I.F.; Moura, D.J.; Saffi, J.; Henriques, J.A.P.; Carvalho, T.S.C.; et al. Potent Antileukemic Action of Naphthoquinoidal Compounds: Evidence for an Intrinsic Death Mechanism based on Oxidative Stress and Inhibition of DNA Repair. J. Braz. Chem. Soc. 2013, 24, 145-163. [CrossRef]

35. Araújo, A.J.; de Souza, A.A.; da Silva Júnior, E.N.; Marinho-Filho, J.D.B.; de Moura, M.A.B.F.; Rocha, D.D.; Vasconcellos, M.C.; Costa, C.O.; Pessoa, C.; de Moraes, M.O.; et al. Growth inhibitory effects of 3'-nitro-3-phenylamino nor-beta-lapachone against HL-60: A redox-dependent mechanism. Toxicol in Vitro 2012, 26, 585-594. [CrossRef] [PubMed]

36. Da Silva Júnior, E.N.; de Moura, M.A.B.F.; Pinto, A.V.; Pinto, M.C.F.R.; de Souza, M.C.B.V.; Araújo, A.J.; Pessoa, C.; Costa-Lotufo, L.V.; Montenegro, R.C.; de Moraes, M.O.; et al. Cytotoxic, Trypanocidal Activities and Physicochemical Parameters of nor- $\beta$-Lapachone-based 1,2,3-Triazoles. J. Braz. Chem. Soc. 2009, 20, 635-643. [CrossRef]

37. Fattal, E.; Barratt, G. Nanotechnologies and controlled release systems for the delivery of antisense oligonucleotides and small interfering RNA. Br. J. Pharm. 2009, 157, 179-194. [CrossRef] [PubMed]

38. Wang, Z.; Chui, W.K.; Ho, P.C. Nanoparticulate Delivery System Targeted to Tumor Neovasculature for Combined Anticancer and Antiangiogenesis Therapy. Pharm. Res. 2011, 28, 585-596. [CrossRef] [PubMed]

39. Farazuddin, M.; Sharma, B.; Khan, A.A.; Joshi, B.; Owais, M. Anticancer efficacy of perillyl alcohol-bearing PLGA microcapsules. Int. J. Nanomed. 2012, 7, 35-47.

40. Kim, I.; Byeon, H.J.; Kim, T.H.; Lee, E.S.; Oh, K.T.; Shin, B.S.; Lee, K.C.; Youn, Y.S. Doxorubicin-loaded highly porous large PLGA microcapsules as a sustained release inhalation system for the treatment of metastatic lung cancer. Biomaterials 2013, 33, 5574-5583. [CrossRef] [PubMed]

41. Jain, A.; Kesharwani, P.; Garg, N.K.; Jain, A.; Nirbhavane, P.; Dwivedi, N.; Banerjee, S.; Iyer, A.K.; Amin, M.C.I.M. Nano-constructed Carriers Loaded With Antioxidant: Boon For Cardiovascular System. Curr. Pharm. Design. 2015, 21, 4456-4464. [CrossRef]

42. Neves, A.R.; Martins, S.; Segundo, M.A.; Reis, S. Nanoscale Delivery of Resveratrol towards Enhancement of Supplements and Nutraceuticals. Nutrients 2016, 8, 131. [CrossRef] [PubMed]

43. Summerlina, N.; Qua, Z.; Pujaraa, N.; Sheng, Y.; Jambhrunkar, S.; McGuckinb, M.; Popat, A. Colloidal mesoporous silica nanoparticles enhance the biological activity of resveratrol. Coll. Surf. B Biointerfaces 2016, 144, 1-7. [CrossRef] [PubMed]

44. Soo, E.; Thakur, S.; Qu, Z.; Jambhrunkar, S.; Parekh, H.S.; Popat, A. Enhancing delivery and cytotoxicity of resveratrol through a dual nanoencapsulation approach. J. Colloid Inter. Sci. 2016, 462, 368-374. [CrossRef] [PubMed]

45. Acharya, G.; Shin, C.S.; McDermott, M.; Mishra, H.; Park, H.; Kwon, I.C.; Park, K. The hydrogel template method for fabrication of homogeneous nano/microcapsules. J. Control. Release 2010, 141, 314-319. [CrossRef] [PubMed]

46. Mundargi, R.C.; Babu, R.V.; Rangaswamy, V.; Patel, P.; Aminabhavi, T.M. Nano/micro technologies for delivering macromolecular therapeutics using poly(D,L-lactide-co-glycolide) and its derivatives. J. Control. Release 2008, 125, 193-209. [CrossRef] [PubMed] 
47. Ateh, D.D.; Leinster, V.H.; Lambert, S.R.; Shah, A.; Khan, A.; Walklin, H.J.; Johnstone, J.V.; Ibrahim, N.I.; Kadam, M.M.; Malik, Z; et al. The intracellular uptake of CD95 modified paclitaxel-loaded poly (lactic-co-glycolic acid) microcapsules. Biomaterials 2011, 32, 8538-8547. [CrossRef] [PubMed]

48. Lin, R.; Ng, L.S.; Wang, C.H. In vitro study of anticancer drug doxorubicin in PLGA-based microcapsules. Biomaterials 2005, 26, 4476-4485. [CrossRef] [PubMed]

49. Zhang, Y.H.; Yue, Z.J.; Zhang, H.; Tang, G.S.; Wang, Y.; Liu, J.M. Temozolomide/PLGA microcapsules plus vatalanib inhibits tumor growth and angiogenesis in an orthotopic glioma model. Eur. J. Pharm. Biopharm. 2010, 76, 371-375. [CrossRef] [PubMed]

50. Ossa, D.H.P.; Lorente, M.; Gil-Alegre, M.E.; Torres, S.; García-Taboada, E.; Aberturas, M.R.; Molpeceres, J.; Velasco, G.; Torres-Suárez, A.I. Local Delivery of Cannabinoid-Loaded Microcapsules Inhibits Tumor Growth in a Murine Xenograft Model of Glioblastoma Multiforme. PLoS ONE 2013, 8, 1-8.

51. Santos, S.G.; Santana, J.V.; Maia, F.F.; Lemos, V.; Freire, V.N.; Caetano, E.W.S.; Cavada, B.S.; Albuquerque, E.L. Adsorption of Ascorbic Acid on the C60 Fullerene. J. Phys. Chem. B 2008, 112, 14267-14272. [CrossRef] [PubMed]

52. Hadad, A.; Azevedo, D.L.; Caetano, E.W.S.; Freire, V.N.; Mendonça, G.L.F.; Neto, P.L.; Albuquerque, E.L.; Margis, R.; Gottfried, C. Two-Level Adsorption of Ibuprofen on $\mathrm{C}_{60}$ Fullerene for Transdermal Delivery: Classical Molecular Dynamics and Density Functional Theory Computations. J. Phys. Chem. C 2011, 115, 24501-24511. [CrossRef]

53. Ukmar, T.; Gaberšček, M.; Merzel, F.; Godec, A. Modus operandi of controlled release from mesoporous matrices: A theoretical perspective. Phys. Chem. Chem. Phys. 2011, 13, 15311-15317. [CrossRef] [PubMed]

54. Chakravarthi, S.S.; Robinson, D.H. Enhanced cellular association of paclitaxel delivered in chitosan-PLGA particles. Int. J. Pharm. 2011, 409, 111-120. [CrossRef] [PubMed]

55. Pérez-Sacau, E.; Díaz-Peñate, R.G.; Estévez-Braun, A.; Ravelo, A.G.; García-Castellano, J.M.; Pardo, L.; Campillo, M.J. Synthesis and pharmacophore modeling of naphthoquinone derivatives with cytotoxic activity in human promyelocytic leukemia HL-60 cell line. J. Med. Chem. 2007, 50, 696-706. [CrossRef] [PubMed]

56. Fieser, L.F.; Fieser, M. Naphthoquinone Antimalarials. XII. The Hooker Oxidation Reaction. J. Am. Chem. Soc. 1948, 70, 3215-3222. [CrossRef] [PubMed]

57. Hooker, S.C. On the Oxidation of 2-Hydroxy-1,4-naphthoquinone Derivatives with Alkaline Potassium Permanganate. J. Am. Chem. Soc. 1936, 58, 1174-1179. [CrossRef]

Sample Availability: Samples of the nor- $\beta$-lapachone $(\mathrm{N} \beta \mathrm{L})$ and $\mathrm{N} \beta \mathrm{L}$-loaded PLGA microcapsules are available from da Silva Júnior E.N. (eufranio@ufmg.br) and Pessoa C. (cpessoa@ufc.br) laboratories. 